\title{
AKSI UNIASIAH (Blood Transfusion Unit) Based on Android With Waterfall
}

\author{
Betty Apriliasari ${ }^{1}$, Nur Sri Utami ${ }^{2}$ Lidia $^{3}$, Asrul Abdullah ${ }^{4}$ \\ ${ }^{1}$ Program Studi Teknik Informatika /Universitas Muhammadiyah Pontianak \\ Jl. Ahmad Yani I No.111 Pontianak/E-mail : betty.apriliasari@unmuhpnk.ac.id \\ ${ }^{2}$ Program Studi Teknik Informatika /Universitas Muhammadiyah Pontianak \\ Jl. Ahmad Yani I No.111 Pontianak/E-mail : nur.utami@unmuhpnk.ac.id \\ ${ }^{3}$ Program Studi Kesehatan Masyarakat/Universitas Muhammadiyah Pontianak \\ Jl. Ahmad Yani I No.111 Pontianak/E-mail : lidia@unmuhpnk.ac.id \\ ${ }^{4}$ Program Studi Teknik Informatika /Universitas Muhammadiyah Pontianak \\ Jl. Ahmad Yani I No.111 Pontianak/E-mail : asrul.abdullah@unmuhpnk.ac.id
}

\section{ARTICLE INFO}

Article history:

Received 12 June 2019

Received in revised form 01 July 2019

Accepted 25 July 2019

Available online 30 July 2019

\begin{abstract}
Teknologi informasi merupakan salah satu teknologi yang sedang berkembang dengan pesat pada saat ini, sehingga informasi yang tersedia dapat berlangsung dengan cepat, efisien serta akurat. Pada Unit Transfusi Darah PMI ini sangat minim pelayanan informasi mengenai ketersediaan darah melalui mobile device sehingga banyak masyarakat yang kurang informasi mengenai persedian darah. Maka perlu ditemukan cara memecahkan masalah yang ada dengan menyediakan sebuah aplikasi berbasis android yang dapat diakses oleh masyarakat. Metode yang digunakan untuk membangun sistem ini menggunakan metode waterfall dan divisualisasikan dengan use case diagram. Hasil dari penelitian ini adalah aplikasi donor darah yang mampu menyediakan data stok darah, jadwal kegiatan donor dan lokasi, serta informasi donor darah.
\end{abstract}

Kata Kunci : darah, unit transfusi darah, android, pmi

\section{Pendahuluan}

Salah satu bagian penting dari tubuh manusia yang memiliki peran yang sangat penting adalah darah. Adanya darah membuat zat-zat seperti sari-sari makanan serta oksigen dapat disalurkan dengan baik ke seluruh organ tubuh. Mengingat pentingnya bagi tubuh manusia membuat kebutuhan akan darah semakin meningkat. Sayangnya, kebutuhan akan darah tidak diimbangi dengan persediaan stok darah yang ada pada tiap unit transfusi darah (UTD). Kemudahan yang didapat dari penerapan teknologi informasi diharapkan dapat membantu orang yang sangat membutuhkan darah. Unit tranfusi darah PMI merupakan lembaga sosial yang bergerak dalam bidang pencarian, pendataan, serta pendistribusian darah[1]. Oleh karena itu lembaga ini perlu memberikan pelayanan yang baik dalam proses penyediaan darah yang dibutuhkan maupun dalam pelayanan informasi kepada masyarakat. Donor darah adalah proses pemberian darah secara sukarela untuk maksud dan tujuan transfusi darah bagi orang lain yang membutuhkan. [2] 
Palang Merah Indonesia sebagai salah satu penyedia darah saat ini terkendala dengan kurangnya persediaan darah bagi para pasien, karena menurut WHO (World Health Organization) yakni badan PBB yang mengurusi kesehatan umum dunia, idealnya ketersediaan darah adalah 2\% dari jumlah penduduk, yang berarti untuk Indonesia saat ini memerlukan 4,6 juta kantong darah, namun PMI hanya mendapatkan kurang dari 0.5\% kebutuhan itu pada tahun 2005. [3] Beberapa hasil penelitian terkait pengembangan aplikasi unit transfusi darah yang telah dilakukan seperti yang dilakukan oleh Hamzah dalam penelitiannya yang berjudul analisa dan rancangan sistem informasi ketersediaan donor darah hidup [4], penelitian Septiana, Zanial Mazalisa danTimur Dali Purwanto yang berjudul membuat aplikasi stock darah pada PMI palembang berbasis android menggunakan jquery[5], dan penelitian yang dilakukan Pratama dan kawan - kawan membuat sistem informasi pelayanan pmi udd di kabupaten Bandung berbasis desktop[6]. Kadek Yogi Saputra, I Made Arsa Suyadnya, dan Ida Bagus Alit Swamardika penelitianya tentang rancang bangun aplikasi komunitas donor darah berbasis web dan android yang dilengkapi layanan informasi geografis[7]. Penelitian lainnya juga dilakukan oleh Robby dkk tentang design build e-donor application for blood donation data collection at PMI kota Surabaya[8].

Berdasarkan hasil wawancara yang dilakukan kepada pihak UTD PMI kota Pontianak, masalah yang dihadapi oleh UTD ini adalah tidak tersedianya sumber daya baik manusia atau media yang melayani permintaan mengenai stok darah yang ada. Selain itu, dari sisi masyarakat masih sedikit yang peduli akan perlu donor darah yang reguler. Harapan yang diinginkan oleh UTD PMI kota Pontianak adalah adanya sebuah aplikasi Android yang dapat diunduh oleh masyarakat kota Pontianak sehingga semua informasi terkait pelayanan dan kegiatan donor darah dapat diketahui. Untuk itu, perlu buat suatu sistem pelayanan donor darah berbasis Android yang diharapkan dapat membantu para pendonor mendapatkan informasi-informasi mengenai prosedur donor darah, jumlah stok darah yang tersedia, jadwal donor kembali bagi pendonor dan informasi kegiatan acara donor darah padahal informasi - informasi merupakan fungsi kegiatan administrasi yang dilakukan pihak Unit Transfusi Darah PMI Pontianak.

\section{Metode Penelitian}

\subsection{Alat dan bahan penelitian}

Alat yang digunakan dalam penelitian ini adalah komputer yang memiliki kemampuan sebagai web server dan server database, mampu mengolah bahasa pemrograman dinamis sisi server berbasis object yaitu PHP, dan aplikasi pengolah kode seperti Android Studio. Bahan penelitian yang diperlukan adalah :

\section{- Kebutuhan data berupa :}

1. Data pendonor reguler

2. Data stok darah

3. Data acara donor darah.

- Kebutuhan informasi berupa :

1. Informasi pendonor perhari

2. Informasi acara donor darah

\subsection{Metode perancangan perangkat lunak}

Metode penelitian yang diterapkan pada penelitian ini adalah dengan pengembangan metode waterfall. Metode waterfall merupakan model pengembangan sistem informasi yang sistematik dan sekuensial[9]. Metode waterfall di bagi menjadi 5 proses yang saling berhubungan satu sama lain yang meliputi : analisis kebutuhan perangkat lunak, perancangan sistem, implementasi, pengujian, pemeliharaan. Pemodelan dari metode Waterfall yang ditunjukkan pada Figure $1[10]$

TRANSFORMATIKA Vol. 17, No. 1, July 2019: 1-66 


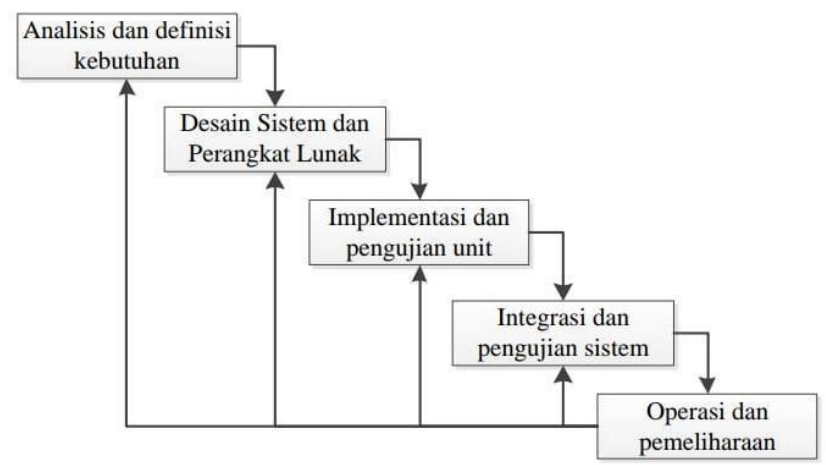

Figure 1.Waterfall model

1. Tahap Analisis dan Definisi Kebutuhan

Langkah ini merupakan analisa terhadap kebutuhan sistem. Pengumpulan data dalam tahap ini bisa melakukan sebuah penelitian, wawancara atau study literatur. Seseorang sistem analisis akan menggali informasi sebanyak-banyaknya dari pengguna sehingga akan tercipta sebuah sistem komputer yang bisa melakukan tugas-tugas yang diinginkan oleh user tersebut. Tahapan ini akan menghasilkan dokumen user requirement atau bisa dikatakan sebagai data yang berhubungan dengan keinginan user dalam pembuatan sistem. Dokumen inilah yang akan menjadi acuan sistem analisis untuk menterjemahkan kedalam bahasa pemrograman. [11]

2. Tahap Desain sistem dan perangkat lunak

Tahapan perancangan sistem mengalokasikan kebutuhan-kebutuhan sistem baik perangkat keras maupun perangkat lunak dengan membentuk arsitektur sistem secara keseluruhan. Perancangan perangkat lunak melibatkan identifikasi dan penggambaran abstraksi sistem dasar perangkat lunak dan hubungannya. [12]

3. Tahap Implementasi dan pengujian unit

Pada tahap ini, perancangan perangkat lunak direalisasikan sebagai serangkaian program atau unit program. Pengujian melibatkan verifikasi bahwa setiap unit memenuhi spesifikasinya. [12]

4. Tahap Integrasi dan pengujian sistem

Unit-unit individu program atau program digabung dan diuji sebagai sebuah sistem lengkap untuk memastikan apakah sesuai dengan kebutuhan perangkat lunak atau tidak. Setelah pengujian, perangkat lunak dapat dikirimkan ke customer. [12]

5. Tahap Pemeliharaan

Biasanya (walaupun tidak selalu), tahapan ini merupakan tahapan yang paling panjang. Sistem dipasang dan digunakan secara nyata. Maintenance melibatkan pembetulan kesalahan yang tidak ditemukan pada tahapan-tahapan sebelumnya, meningkatkan implementasi dari unit sistem, dan meningkatkan layanan sistem sebagai kebutuhan baru. [12]

\section{Hasil dan Pembahasan}

\subsection{Analisa kebutuhan}

1) Identifikasi Masalah

Setelah melakukan kegiatan wawancara dan observasi di UTD PMI Kota Pontianak, maka dapat ditemukan beberapa permasalahan yang muncul antara lain: 
- Kurangnya informasi mengenai stok darah yang disampaikan kepada masyarakat menjadi salah satu penyebab masyarakat bingung untuk melihat persediaan darah pada PMI Kota Pontianak dalam sewaktu-waktu.

- PMI sekarang menerapkan donor darah suka rela namun kesadaran masyarakat mengenai pentingnya berdonor darah sangat kurang.

2) Analisa Sistem

Perancangan aplikasi Aksi Uniasiah berbasis Android ini merupakan sistem informasi yang memudahkan pengguna mencari informasi tentang stok darah serta kegiatan sosial yang dilakukan oleh PMI Kota Pontianak. Harapan dari pembuatan sistem informasi Aksi Uniasiah ini agar masyarakat luas dapat dengan mudah mendapatkan informasi yang ada di PMI Kota Pontianak, dapat meningkatkan kesadaraan masyarakat bahwa pentingnya donor bagi kesehatan serta membantu masyarakat yang membutuhkan donor darah.

3) Kebutuhan data

Data yang dibutuhkan dalam sistem informasi donor darah ini diantaranya: Data pendonor tetap, data jadwal/event yang dilakukan pihak PMI, data persediaan darah dalam sewaktu-waktu.

4) Kebutuhan Fungsional

Kebutuhan fungsional adalah analisa mengenai fitur-fitur apa saja yang akan di terapkan pada aplikasi "Aksi Uniasiah" ini. Fitur-fitur tersebut antara lain:

1. Sistem dapat menampilkan menu utama.

2. Sistem dapat melakukan input,update, delete stok darah yang tersedia .

3. Sistem dapat menampilkan jadwal kegiatan sosial seperti donor darah yang dilaksanakan oleh pmi.

4. Sistem dapat menampilkan info pelayanan donor darah.

5. Sistem dapat menampilkan tentang / about aplikasi

5) Kebutuhan Non Fungsional

Kebutuhan non fungsional adalah sebuah kebutuhan yang dilakukan untuk mengetahui spesifikasi kebutuhan dan kelayakan dari sebuah sistem atau aplikasi yang telah dibuat. Spesifikasi kebutuhan melibatkan kebutuhan perangkat lunak (Software), perangkat keras (Hardware), sumberdaya manusia (Brainware), dan analisis kelayakan.

\subsection{Desain Sistem}

A. Use case diagram

Use case diagram merupakan fungsionalitas yang disediakan sistem sebagai unit - unit yang saling bertukar pesan antar unit atau aktor [13]. Use case diagram dari aplikasi AKSI UNISIAH seperti yang ditunjukkan pada Figure 2 :

TRANSFORMATIKA Vol. 17, No. 1, July 2019: 1-66 


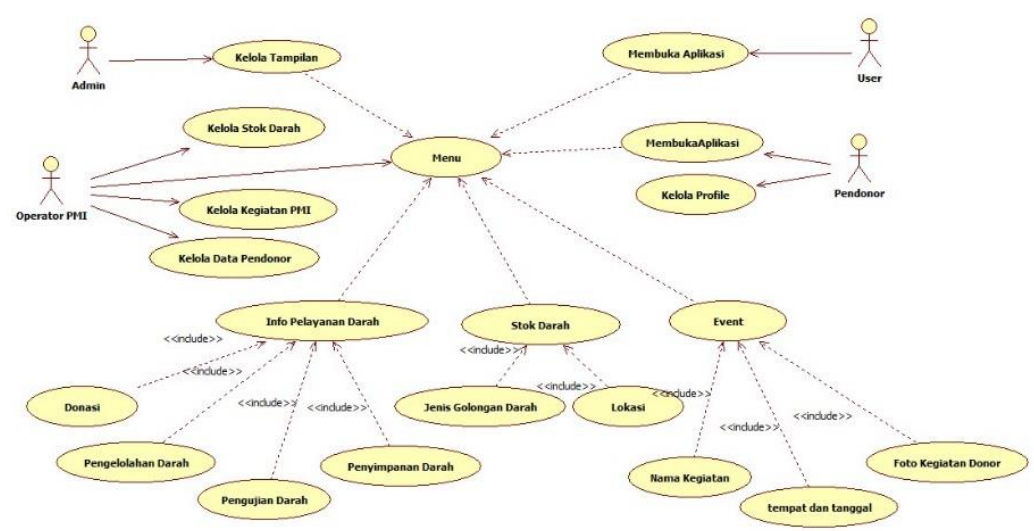

Figure 2. Use case diagram

B. Activity diagram

Activity diagram atau diagram aktivitas adalah sekumpulan aktivitas yang dilakukan oleh tiap - tiap user di dalam aplikasi. Untuk activity diagram membuka dan menutup aplikasi Android ini ditunjukkan pada Figure 3.

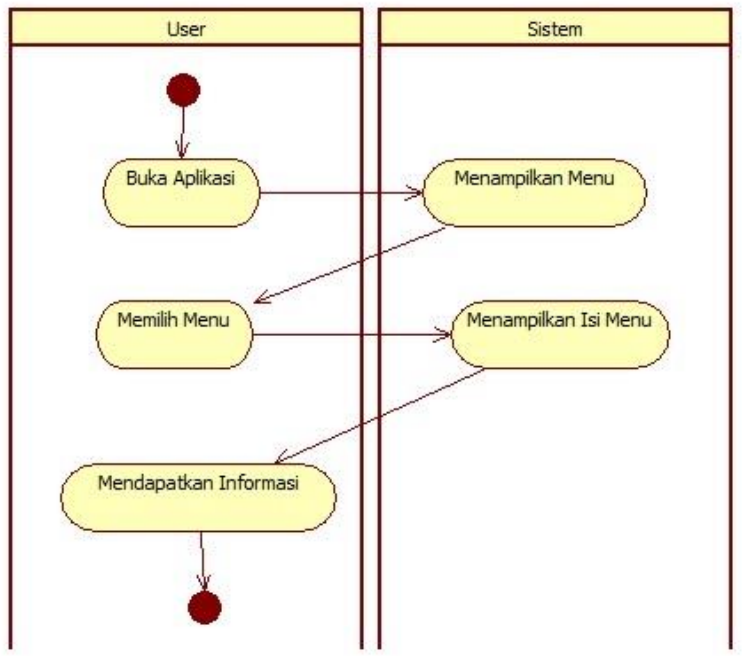

Figure 3. Activity diagram membuka dan menutup aplikasi

Sedangkan, activity diagram untuk keseluruhan di aplikasi Android ini ditunjukkan pada Figure 4. 


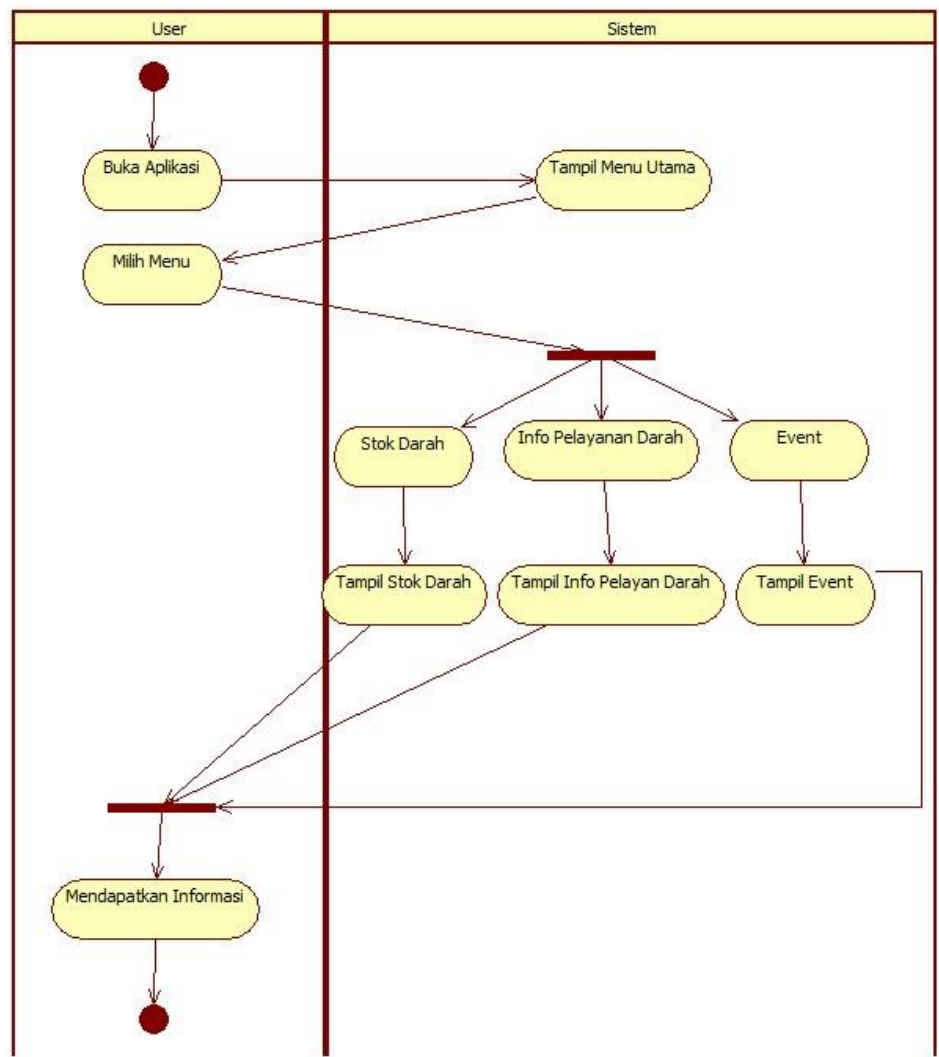

Figure 4. Activity diagram aplikasi

\subsection{Implementasi Sistem}

Hasil desain tampilan :

a) Tampilan Login

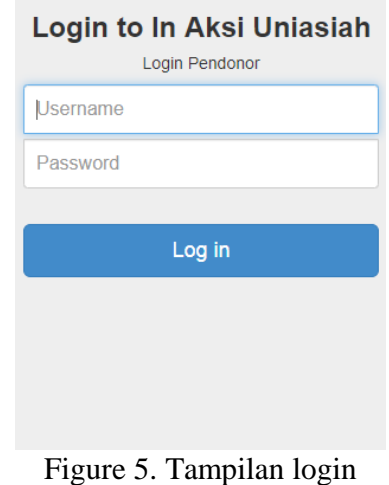

b) Tampilan Dashboard

TRANSFORMATIKA Vol. 17, No. 1, July 2019: 1-66 


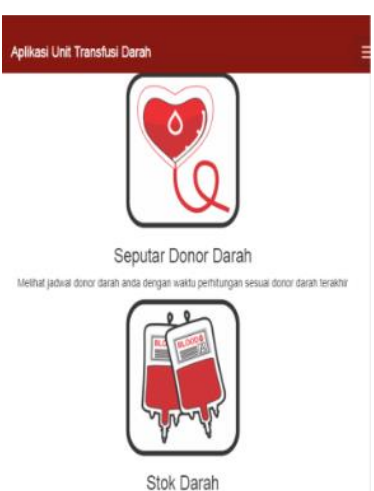

Figure 6.Tampilan dahsboard

c) Tampilan pencarian stok darah

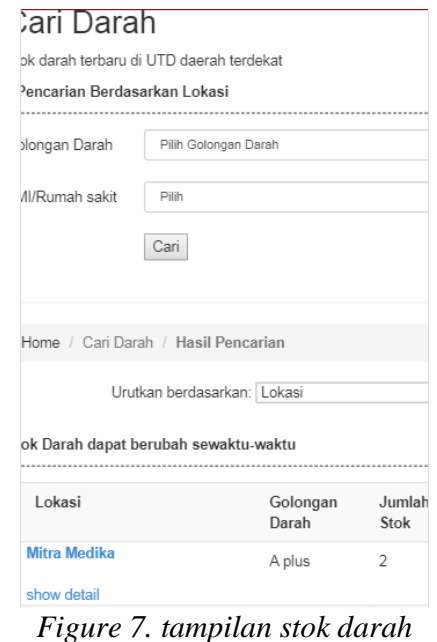

\subsection{Integrasi dan Pengujian Sistem}

Pengujian black box merupakan metode pengujian yang digunakan untuk menguji fitur pada aplikasi apakah aplikasi komunitas donor darah berbasis web dan Android sudah sesuai dengan tujuan yang harapkan. Dari seluruh pengujian terhadap aplikasi berbasis web dan Android dengan menggunakan metode black box seluruh fungsi yang ditampilkan sudah berjalan dengan baik dan sesuai dengan tujuan yang diharapkan. Seluruh fitur dan fungsi diujikan satu per satu dan hasilnya dicatat sebagai bukti bahwa seluruh fitur dan fungsi dari aplikasi sudah berjalan sesuai tujuan yang diharapkan. Pengujiannya dapat dilihat pada Table 1 .

Table 1. Pengujian pada halaman admin

\begin{tabular}{|c|c|c|c|}
\hline \multicolumn{4}{|c|}{ Kasus dan hasi uji coba (data normal) } \\
\hline Data Masukan & $\begin{array}{l}\text { Hasil Yang } \\
\text { Diharapkan }\end{array}$ & Hasil Pengamatan & Kesimpulan \\
\hline Klik tombol login & $\begin{array}{l}\text { Masuk ke halaman } \\
\text { dashboard admin }\end{array}$ & $\begin{array}{l}\text { Masuk ke halaman } \\
\text { dashboard admin }\end{array}$ & Diterima \\
\hline Tambah artikel & Artikel bertambah & Artikel bertambah & Diterima \\
\hline Hapus artikel & Artikel terhapus & Artikel terhapus & Diterima \\
\hline Edit artiel & Artikel teredit & Artikel teredit & Diterima \\
\hline Tambah galeri & Galeri bertambah & Galeri bertambah & Diterima \\
\hline Hapus galeri & Galeri terhapus & Galeri terhapus & Diterima \\
\hline Edit galeri & Galeri teredit & Galeri teredit & Diterima \\
\hline Tambah operator & Operator bertambah & Operator bertambah & Diterima \\
\hline Hapus operator & Operator terhapus & Operator terhapus & Diterima \\
\hline
\end{tabular}

AKSI UNIASIAH (Blood Tranfusion Unit) Base On Android With Waterfall (Betty Apriliasari) 


\begin{tabular}{|l|l|l|l|}
\hline Edit operator & Operator terdeit & Operator teredit & Diterima \\
\hline Tambah pendonor & Pendonor bertambah & Pendonor bertambah & Diterima \\
\hline Hapus pendonor & Pendonor terhapus & Pendonor terhapus & Diterima \\
\hline Edit pendonor & Pendonor teredit & Pendonor teredit & Diterima \\
\hline Tambah slide & Slide bertambah & Slide bertambah & Diterima \\
\hline Hapus slide & Slide terhapus & Slide terhapus & Diterima \\
\hline Edit slide & Slide teredit & Slide teredit & Diterima \\
\hline Tambah tab menu & Tab menu bertambah & Tab menu bertambah & Diterima \\
\hline Hapus tab menu & Tab menu terhapus & Tab menu terhapus & Diterima \\
\hline Edit tab menu & Tab menu teredit & Tab menu teredit & Diterima \\
\hline Tambah akun admin & $\begin{array}{l}\text { Akun admin } \\
\text { bertambah }\end{array}$ & $\begin{array}{l}\text { Akun admin } \\
\text { bertambah }\end{array}$ & Diterima \\
\hline Hapus akun admin & Akun admin terhapus & Akun admin terhapus & Diterima \\
\hline Edit akun admin & Akun admin teredit & Akun admin teredit & Diterima \\
\hline Stok dara & Melihat stok darah & Melihat stok darah & Diterima \\
\hline Edit password & Password teredit & Password teredit & Diterima \\
\hline
\end{tabular}

Untuk pengujian pada halaman operator ditunjukkan pada Table 2.

Table 2. pengujian pada halaman operator

\begin{tabular}{|l|l|l|l|}
\hline \multicolumn{5}{|c|}{ Kasus dan hasil uji coba (data normal) } \\
\hline Data masukan & Hasil yang diharapkan & Hasil pengamatan & kesimpulan \\
\hline Klik tombol login & $\begin{array}{l}\text { Masuk ke halaman } \\
\text { dashboard operator }\end{array}$ & $\begin{array}{l}\text { Masuk ke halaman } \\
\text { dashboard operator }\end{array}$ & Diterima \\
\hline Tambah stok darah & Stok dara bertambah & Stok dara bertambah & Diterima \\
\hline Hapus stok darah & Stok dara terhapus & Stok dara terhapus & Diterima \\
\hline Edit stok darah & Stok dara teredit & Stok dara teredit & Diterima \\
\hline Tambah pendonor & Pendonor bertambah & Pendonor bertambah & Diterima \\
\hline Hapus pendonor & Pendonor terhapus & Pendonor terhapus & Diterima \\
\hline Edit pendonor & Pendonor teredit & Pendonor teredit & Diterima \\
\hline Edit password & Password teredit & Password teredit & Diterima \\
\hline Data darah & Melihat data darah & Melihat data darah & Diterima \\
\hline
\end{tabular}

Untuk pengujian pada halaman operator ditunjukkan pada Table 3.

Table 3. pengujian pada halaman pendonor

\begin{tabular}{|c|c|c|c|}
\hline \multicolumn{4}{|c|}{ Kasus dan hasi uji coba (data normal) } \\
\hline Data Masukan & $\begin{array}{l}\text { Hasil Yang } \\
\text { Diharapkan }\end{array}$ & Hasil Pengamatan & Kesimpulan \\
\hline Klik tombol login & $\begin{array}{l}\text { Masuk ke halaman } \\
\text { dashboard pendonor }\end{array}$ & $\begin{array}{l}\text { Masuk ke halaman } \\
\text { dashboard pendonor }\end{array}$ & Diterima \\
\hline Edit password & Password teredit & Password teredit & Diterima \\
\hline Status donor & Melihat staus donor & Meihat status donor & Diterima \\
\hline Lihat biodata & Melihat biodata & Melihat biodata & Diterima \\
\hline
\end{tabular}

Untuk pengujian pada halaman operator ditunjukkan pada Table 4.

Table 4. pengujian pada halaman pengguna umum

\begin{tabular}{|l|l|l|l|}
\hline \multicolumn{4}{|c|}{ Kasus dan hasi uji coba (data normal) } \\
\hline \multicolumn{1}{|c|}{ Data Masukan } & \multicolumn{1}{c|}{$\begin{array}{c}\text { Hasil Yang } \\
\text { Diharapkan }\end{array}$} & Hasil Pengamatan & Kesimpulan \\
\hline Stok darah & Melihat stok darah & Melihat stok darah & Diterima \\
\hline Syarat pengambilan & Melihata sayarat & Melihata sayarat & Diterima \\
\hline
\end{tabular}

TRANSFORMATIKA Vol. 17, No. 1, July 2019: 1-66 


\begin{tabular}{|l|l|l|l|}
\hline darah & pengambilan darah & pengambilan darah & \\
\hline Syarat donor darah & $\begin{array}{l}\text { Melihat syarat donor } \\
\text { darah }\end{array}$ & $\begin{array}{l}\text { Melihat syarat donor } \\
\text { darah }\end{array}$ & Diterima \\
\hline Jadwal donor darah & $\begin{array}{l}\text { Melihat jadwal donor } \\
\text { darah }\end{array}$ & $\begin{array}{l}\text { Melihat jadwal donor } \\
\text { darah }\end{array}$ & Diterima \\
\hline
\end{tabular}

3.5 Operasional dan Perawatan

Operasionalisasi dirancang agar dapat dilakukan di PMI Kota Pontianak. Sedangkan pemeliharaan sistem dirancang dengan dilakukannya pemeriksaan periodik terhadap data pada aplikasi.

\section{Kesimpulan}

Berdasarkan penelitian yang telah dilakukan, maka dapat diambil kesimpulan sebagai berikut:

a. Dengan adanya Aplikasi ini, instansi dapat menyebarkan data stok darah, jadwal donor darah, serta memperluas informasi atau berita mengenai donor darah serta bisa tanya jawab lewat aplikasi android.

b. Sistem informasi ini di harapkan dapat membantu meningkatkan kesadaraan masyarakat pentingnya donor darah .

c. Sistem informasi ini memberikan informasi mengenai syarat donor darah serta apa saja syarat dalam pengambilan darah di PMI Kota Pontianak.

d. Sistem informasi donor darah ini dikembangkan menggunakan metode Waterfall akan memberikan output/keluaran berupa grafik pertumbuhan pengguna aplikasi dan aktivitas donor darah setiap bulan.

\section{Ucapan Terima Kasih}

Penulis mengucapkan terima kasih kepada Direktorat Jenderal Pembelajaran dan Kemahasiswa Kemenristekdikti yang telah memberi dukungan finansial terhadap penelitian ini melalui Program Kreativitas Mahasiswa (PKM) tahun 2018.

\section{References}

[1] P.M.Indonesia, “Aktivitas: Pelayanan: Donor Darah.” [Online]. Available: http://www.pmi.or.id/index.php/aktivitas/pelayanan/donor-darah/pelayanandonordarah.html. [Accessed: 10-Jun-2019].

[2] C. A. Sugiatno and T. M. Zundi, "Rancang Bangun Aplikasi Donor Darah Berbasis Mobile di PMI Kabupaten Bandung," KOPERTIP J. Ilm. Manaj. Inform. dan Komput., vol. 1, no. 1, pp. 11-17, 2017.

[3] A. Marceline, H. Anra, and H. S. Pratiwi, "Rancang Bangun Layanan Jemput Darah Berbasis Android," J. Sist. dan Teknol. Inf., vol. 5, no. 1, pp. 31-35, 2017.

[4] Hamzah, "Analisa dan rancangan sistem informasi ketersediaan donor darah hidup," $J$. Ilm. Teknol. Inf., vol. 1, no. 2, pp. 15-20, 2015.

[5] Z. Septiana, Mazalisa, and T. D. Purwanto, "Aplikasi Stock Darah Pada PMI Palembang Berbasis Android Menggunakan Jquery,” pp. 1-15, 2015.

[6] A. H. Nugraha, "Sistem Informasi Pelayanan Pmi Udd Di Kabupaten Bandung Berbasis Desktop," pp. 1-22, 2014.

[7] K. Y. Saputra, I. M. A. Suyadnya, and I. B. A. Swamardika, "Rancang Bangun Aplikasi Komunitas Donor Darah Berbasis Web Dan Android Yang Dilengkapi Layanan Informasi Geografis," vol. 3, no. 2, 2016.

[8] R. K. Budhi, D. T. Hidayat, and F. L. Sugito, "Design Build E-Donor Application for Blood Donation Data Collection at PMI Kota Surabaya," TRANSFORMATIKA, vol. 15, 
no. 1, pp. 8-16, 2017.

[9] R. S. Pressman, Rekayasa Perangkat Lunak: Pendekatan Praktisi(Buku Dua). Yogyakarta: Andi Publisher, 2002.

[10] I. Sommerville, Software Engineering. 9th Edition. Boston: Addison-Wesley, 2011.

[11] C. Tristianto, "Penggunaan Metode Waterfall Untuk Pengembangan Sistem Monitoring Dan Evaluasi Pembangunan Pedesaan," J. Teknol. Inf. ESIT, vol. 12, no. 1, pp. 8-22, 2018.

[12] G. W. Sasmito, "Penerapan Metode Waterfall Pada Desain Sistem Informasi Geografis Industri Kabupaten Tegal," J. Inform. Pengemb. IT, vol. 2, no. 1, pp. 6-12, 2017.

[13] Y. Sugiarti, Analisis dan Perancangan UML (Unified Modelling Language). Yogyakarta: Graha Ilmu, 2013.

TRANSFORMATIKA Vol. 17, No. 1, July 2019: 1-66 